особливостей учнів; бажання і прагнення щодо оволодіння глибокими теоретичними знаннями та передовим досвідом учителів-новаторів; зацікавленість результатом своєї діяльності та потребою в ії апробації [1, c. 48].

\title{
Література:
}

1. Бабешко О. П., Завадич В. М. Чинники оптимізації післядипломної підготовки вчителів фізичної культури // Освіта на Луганщині, № 2, 2004. С. 48-49.

2. Закон «Про загальну середню освіту» від 13.05.1999 // www.edication.gov.ua 3. Концепція 12-річної середньої загальноосвітньої школи // Директор школи. - № 1, 2002. С. 11-15.

3. Навчальна програма 3 фізичної культури для загальноосвітніх навчальних закладів10-11 класи. Рівень стандарту Робоча група, яка здійснила розроблення навчальної програми відповідно до наказу № 451 Міністерства освіти і науки України від 22.03.2017 p.: М. В. Тимчик, Є. Ю. Алексєйчук, В. В. Дерев'янко, В. М. Срмолова, В. О. Сілкова, 2017. 80 с.

4. Онищук С. О. «Впровадження нової української школи на уроках фізичної культури» Науковий Часопис Національного педагогічного університету імені М. П. Драгоманова. Серія 16. Творча особистість учителя: проблеми теорії і практики: збірник наукових праць, 2020. C. $83-87$.

DOI https://doi.org/10.30525/978-9934-588-80-8-1.62

\section{ПЕРСОНОЛОГІЯ В СИСТЕМІ ПІДГОТОВКИ МАЙБУТНІХ УЧИТЕЛІВ}

\author{
Процик Г. М. \\ аспірантка кафедри педагогіки та менеджменту освіти \\ Тернопільський начіональний педагогічний університет \\ імені Володимира Гнатюка \\ м. Тернопіль, Украӥна
}

У період трансформаційних процесів, що відбуваються в освітній галузі, $\epsilon$ необхідністю виокремлення педагогічних персоналій та їх пріоритетних ідей у процесі підготовки майбутніх вчителів.

Із метою вивчення популярності праць вітчизняних і зарубіжних вчених, які застосовуються в навчальному процесі, нами було опитано 16 236 
експертів - викладачів закладів вищої освіти. На запитання відповіли доктори наук у галузі педагогіки Чернівецького націона-льного університету імені Ю. Федьковича, Черкаського національного університету імені Б. Хмельницького та Тернопільського національного економічного університету. Дослідження проводилося у 2019 році.

На запитання: «Праці яких вітчизняних і зарубіжних учених $\epsilon$ найбільш значимі для викладачів?», відповіді респондентів можна об'єднати у два блоки. До першого віднесено вітчизняних науковців (10 осіб), до другого - зарубіжних (6 осіб). Серед вітчизняних науковців викладачі підкреслили значимість праць К. Д. Ушинського, В. О. Сухомлинського, М. С. Грушевського, А. І. Кузьмінського, І. Д. Беха та О. Я. Савченко.

Зауважимо, що у відповідях респонденти виокремили праці відомого вітчизняного педагога XIX ст. К. Д. Ушинського, який написав чимало шкільних підручників, літературних творів, монографій, пов'язаних із вихованням, навчанням і розвитком підростаючого покоління. Цінними для сучасної науки $є$ ідеї Ушинського щодо розвитку активності як форми, в якій здійснюється свідоме навчання учня.

Зазначимо, що в історії педагогічної науки В. О. Сухомлинський займає почесне місце як знаний педагог, гуманіст і мислитель.

Окрім педагогів респонденти згадали ім'я великого українського історика М. С. Грушевського, основна праця якого - 10-ти томна монографія «Історія України-Русі», вважається найповнішою історією нашої держави.

Разом 3 тим, опитувані відмітили педагога-сучасника Савченко О. Я., що акцентує увагу на дослідженні пізнавальної самостійності молодших школярів, якості шкільної освіти та іiі модернізації.

Підсумовуючи результати першого блоку відповідей зазначимо, що велика педагогічна спадщина вітчизняних науковців, на думку опитаних, має місце в сучасному освітньому процесі, сприяє ефективному навчанню та вихованню учнів.

Щодо вибору зарубіжних персоналій (другий блок), то респонденти вважають, що майбутнім педагогам необхідно знати й уміти застосовувати в майбутній професійній діяльності досконалі й раціональні методи навчання «батька дидактики» та педагогічної науки Я. А. Коменського; пріоритетні принципи та форми роботи щодо вільного розвитку дітей за методикою М. Монтессорі; ідеї гуманної педагогіки, особистісного підходу до дітей під час навчального процесу, запропоновані Ш. Амонашвілі. 
Разом 3 тим викладачі у відповідях назвали прізвища радянських педагогів XX ст.: I. Я. Лернера, що досліджував основи дидактики, написав багато праць про методи навчання, обгрунтував сучасні підходи в навчанні; М. М. Скаткіна, що займався методологією педагогічної науки, вдосконаленням процесу й змісту навчання, досліджував проблеми дидактики.

Окрім того експерти підкреслили значимість праць польського педагога В. Оконя, який досліджував фундаментальні основи навчального процесу, писав праці про історію школи, досліджував особливості проблемного навчання, автором педагогічного словника.

Отримані результати опитування свідчать про те, що в процесі викладання педагогічних дисциплін необхідним $є$ вивчення пріоритетних напрямів наукових шкіл - як вітчизняних, так і зарубіжних, які зробили вагомий внесок у науку та не втратили своєї актуальності сьогодні, а також новітні підходи в навчальному та виховному процесі, що впливатимуть на формування основ професіоналізму майбутнього вчителя.

DOI https://doi.org/10.30525/978-9934-588-80-8-1.63

\title{
ЗАБЕЗПЕЧЕННЯ ІНДИВІДУАЛЬНОГО ПІДХОДУ В ОСВІТНЬОМУ ПРОЦЕСІ ШКОЛИ ПЕРШОГО СТУПЕНЯ
}

\author{
Толмачова I. М. \\ кандидат педагогічних наук, дочент, \\ професор кафедри педагогіки, психології, початкової освіти \\ та освітнього менеджменту \\ Комунальний заклад «Харківська гуманітарно-педагогічна академія» \\ Харківської обласної ради \\ Шпитальна Н. С. \\ здобувач вищої освіти психолого-педагогічного факультету \\ Комунальний заклад «Харківська гуманітарно-педагогічна академія» \\ Харківської обласної ради \\ м. Харків, Украӥна
}

Основним вектором розвитку сучасного світу є глобалізація, демократія, соціально-культурні перетворення. Успішний поступ України можливий за умови прогресу не лише соціально-економічних i політичних перетворень, а й забезпечення високого рівня культури та 238 